\title{
The Effect of Work Expectations and Family Environment on Interest in Continuing Postgraduate Studies (S2) in Economics Education Students
}

\author{
Suharmi; Hilyati Milla; Bahrin \\ Economic Education, Muhammadiyah University of Bengkulu, Indonesia \\ http://dx.doi.org/10.18415/ijmmu.v8i9.2857
}

\begin{abstract}
Someone who continues his studies is something that needs to be done in achieving his goals. A person in continuing his studies at a higher level is influenced by various factors including work expectations and the environment. Therefore, the purpose of this research is to determine the effect of work expectations and family environment on the interest in continuing postgraduate education (S2) in economic education students. The methodology of this research is ex-post facto with a quantitative approach. Respondents in this research were students of economic education at the University of Muhammadiyah Bengkulu (UMB) class of 2016 which amounted to 60 students who were taken with a total sampling technique. Methods of data analysis using multiple regression. The results of the research are as follows: 1). Work expectations have a positive and significant effect on interest in continuing postgraduate education (S2), 2). Family environment has a positive and significant effect on interest in continuing postgraduate education (S2), and 3). Work expectations and family environment together affect the interest in continuing postgraduate education (S2) by $30.60 \%$ and $69.40 \%$ influenced by variables outside this research.
\end{abstract}

Keywords: Work Expectations; Family Environment; Interests; Postgraduate; Economics Education

\section{Introduction}

Education is very important for a system in a country, education is a necessity for every level of society (Efendi, Indartono, \& Sukidjo., 2019). Regarding the very importance of education for every society, every society of course always wants to continue their education to a higher level. A person in continuing education at a higher level is certainly influenced by various factors. These factors will increase the social development of each individual child. In social development, there is the growth of intellectual intelligence, emotional intelligence, and spiritual intelligence. (Pangestu, Muhyadi, \& Efendi, 2019)

One's factors in continuing education at a higher level include family socioeconomic conditions and work expectations (Taufik \& Kurniawati, 2020). Work expectations are known to have a positive and significant influence on interest in continuing postgraduate education (Ulfa, 2018). The same thing was also found by Sumakta (2015) where work expectations had a positive effect on interest in continuing master's education. 
In addition to work expectations, there are also family environmental conditions that affect someone in continuing their postgraduate education. Research conducted by Wiyono (2015) found that the condition of the family environment had a positive and significant effect on the interest in continuing postgraduate education. The condition of the family environment also has a positive and significant influence on interest in continuing postgraduate studies. (Salima, 2019)

Based on the phenomena that occur and several research results, it can be seen that work expectations and family environmental conditions have a relationship with interest in continuing postgraduate education. So the purpose of this research is to determine the effect of work expectations and family environmental conditions on interest in continuing postgraduate education. So that in the future it can contribute to one's decision-making policies in continuing postgraduate education.

\section{Work Expectations}

Expectations are various outputs that can potentially be used to determine the choice of what action to take. Each alternative output has a value or value that refers to an interest in someone. Alternative outputs, also called personal goals, can be realized or not realized by the person concerned (Porter \& Lawler, 1968). Expectations or expectations of a person's perception of behavior that is appropriate for his role or position or a person's perception of the role of others in the organization (Blanchard \& Hersey, 1996). Expectations are expectations from someone. (Yusuf \& Efendi, 2019)

Work is something that is issued by someone as a profession, deliberately done to generate the desired income. Work can also be interpreted as energy expenditure for activities needed by a person to achieve certain goals. The main purpose of work is generally just to make money, so the higher the salary, the more interested a person is in the work. This is because human needs for food, drink, clothing, and housing will be fulfilled if they have money. So that some people think money is everything (Ulfa, 2018). It can be concluded that work expectation is an interest in a work or profession that is expected by individuals to achieve the desired goals in order to generate income to meet human needs.

\section{Family Environment}

The environment includes all the conditions that in some way affect our behavior, growth, development, or life processes except for the genes, and not genes can also be viewed as preparing the environment for other genes (Sartain, 1989). The environment influences directly or indirectly. Direct influences such as family, peers, while indirect influences such as television, radio, internet, and other mass media. (Ulfa, 2018)

The family is the first and foremost educational institution in laying the foundation of character in a child (Syarbini, 2014). According to Ikhsan (2008), the family is the first and foremost educational institution for the community, because in the family then children are born and developed into adults. The form and content as well as the ways of education in the family will always affect the growth and development of character, character, and personality of each human being.

The family environment is the primary grouping consisting of a small number of people because of blood relations. The family can be in the form of a nuclear family (father, mother, and children), or an extended family (grandfather, grandmother, sister, brother-in-law, maid). (Umar and La Sulo, 2005). It can be concluded that the family environment is a condition in the family consisting of father, mother, children, and other families, which is related to the way parents educate relationships between family members, home atmosphere, family economic conditions, and understanding of parents. The family environment is the main environment for children's education. There are several factors that affect the family, namely as follows: 1). How parents educate, 2). Relations between members, 3). Home 
atmosphere, 4). Family economic situation, 5). Understanding parents, 6). Cultural background. (Slameto, 2010)

\section{Interest}

Interest is a persistent tendency to pay attention and remember some activities. Activities that are of interest to someone, are considered continuously accompanied by a sense of pleasure (Slameto, 2010). Interest means a high tendency and excitement or a great desire for something (Syah, 2012). According to Ulfa (2018), interest has a big influence on learning activities, because if the lessons learned are not in accordance with the student's interests, then he will not study seriously. Based on this opinion, it can be concluded that interest is a person's tendency to like and be interested in a particular object by giving greater attention to the object.

Interest is very functional for humans because it can direct a person to achieve his life goals so that it can bring people to things that are considered unnecessary to become something useful in themselves because of the emergence of awareness to fulfill their life needs without burdening others. In addition, interest can also provide a person's view of life or one's entire treasury. (Witherington, 1999)

Interest is influenced by various factors including internal factors, namely as follows: 1). Health, 2). Intelligence, 3). Motivation and external factors are as follows: 1). Family, 2). School, 3). Society, and 4). The surrounding environment (Djaali, 2012). While Slameto (2010) the factors that influence interest are internal and external, internal factors are 1). Biological factors, 2). Psychological factors, 3). Fatigue factor, while the external influencing factors are: 1). Family factors, 2). school factor, 3). Community factors.

\section{Research Framework and Hypothesis}

\section{The Effect of Work Expectations on Interest in Continuing Postgraduate Studies (S2)}

Research conducted by Sumakta (2015) found that work expectations have a positive effect on interest in continuing master's studies. Research conducted by Ulfa (2018) that work expectations have a positive and significant effect on interest in continuing master's education. The same thing was found in research conducted by Taufik and Kurniawati (2020) which found that work opportunities or work expectations had a positive and significant effect on interest in continuing education. So it can be concluded that work expectations have a positive and significant influence on the interest in continuing master's education.

$\mathrm{H}_{1}$ : Work Expectations have a positive and significant effect on interest in continuing Postgraduate Studies (S2).

\section{The Effect of Family Environment on Interest in Continuing Postgraduate Studies (S2)}

Research conducted by Wiyono (2015) found that the condition of the family environment had a positive and significant effect on the interest in continuing postgraduate education. The condition of the family environment also has a positive and significant influence on interest in continuing postgraduate studies (Salima, 2019). The same thing was also found by Ulfa (2018) and Taufik and Kurniawati (2020) that the family environment has a positive and significant effect on interest in continuing master's education. So it can be concluded that the family environment has a positive and significant influence on the interest in continuing master's education.

$\mathrm{H}_{1}$ : Family Environment have a positive and significant effect on interest in continuing Postgraduate Studies (S2). 
Based on various theoretical explanations, research findings, and developing hypotheses regarding work expectations and family environment on interest in continuing master's education. Then the research framework in (Figure 1) is as follows:

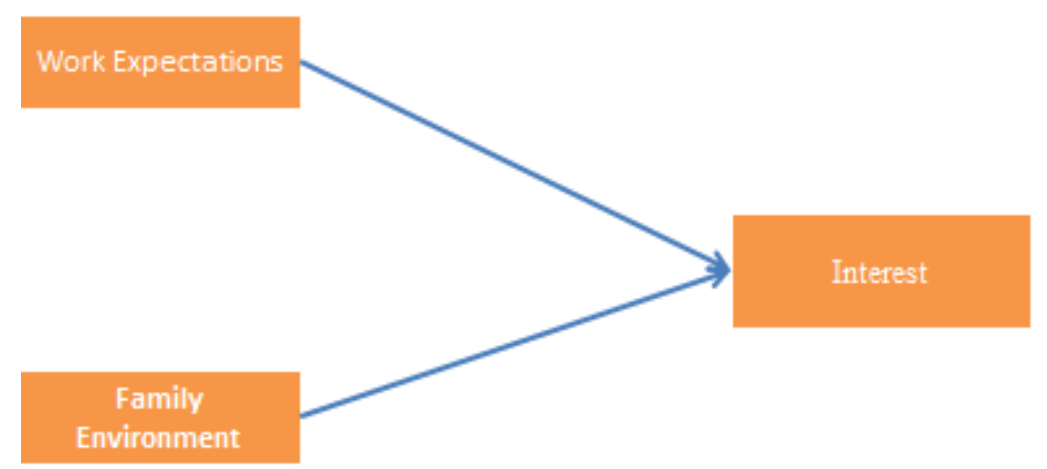

Figure 1. Research Framework

\section{Methodology}

In this research using the type of ex-post-facto research with a quantitative approach, according to Sugiyono (2015), ex-post-facto is research conducted to examine events that have occurred and then trace back to find out the factors that can cause the occurrence of events. that. The population in this research amounted to 60 respondents who were sourced from students of the Economic Education University of Muhammadiyah Bengkulu class of 2016, the sampling in this research used the total sampling technique or all populations were used as research samples. (Efendi et al, 2020)

\section{Findings and Discussion}

Table 1 below is the results of the regression analysis of the research data, with the results of the research as follows:

Tabel 1. Hasil Analisis Regresi

\begin{tabular}{llll}
\hline Variable & Koef. Regression (B) & T Statistic & Sig \\
Work Expectations & 0.268 & 2.116 & 0.039 \\
Family Environment & 0.467 & 4.018 & 0.000 \\
Constant & 33.793 & \\
$\mathrm{R}$ & 0.553 & \\
$\mathrm{R}^{2}$ & 0.306 & \\
F Statistic & 12.551 & \\
Sig & 0.000 & \\
\hline
\end{tabular}

\section{The Effect of Work Expectations on Interest in Continuing Postgraduate Studies (S2)}

Based on the results of research that has been analyzed there is a positive influence that work expectation on interest in continuing master's studies. This is indicated by the regression coefficient value of 0.268 . At the $5 \%$ significance level, it is known that the t-count value is 2.116 with a significance of 0.039. So it can be concluded that the higher the work expectation, the higher the interest in continuing 
the master's study. On the other hand, the lower the work expectations, the lower the interest in continuing their master's studies.

Based on the results of this research, it is supported by the results of research conducted by Sumakta (2015) and Ulfa (2018) which found that work expectations have a positive and significant effect on interest in continuing master's studies. The same thing also shows that work expectations have a positive and significant effect on interest in continuing master's studies. (Taufik \& Kurniawati, 2020)

\section{The Effect of Family Environment on Interest in Continuing Postgraduate Studies (S2)}

Based on the results of the research that has been analyzed there is a positive influence that the work environment has on the interest in continuing master's studies. This is indicated by the regression coefficient value of 0.467 . At the 5\% significance level, it is known that the t-count value is 4.018 with a significance of 0.000 . So it can be concluded that the higher the family environment, the higher the interest in continuing master's studies. On the other hand, the lower the family environment, the lower the interest in continuing master's studies.

Based on the results of this research, it is supported by the results of research conducted by Wiyono (2015) and Salama (2019) which found that the family environment had a positive and significant effect on interest in continuing master's studies. The same thing also shows that the family environment has a positive and significant effect on interest in continuing master's studies. (Ulfa, 2018, and Taufik \& Kurniawati, 2020)

\section{R Square Determination Coefficient (R2)}

The results of the research indicate that there is a positive and significant influence on students' interest in continuing their Master's Degree Study, which is influenced by work expectations and family environment. This is indicated by the results of the test results with $\mathrm{F}$ test which obtained a calculated $\mathrm{F}$ value of 12,551 with an $F$ significance value of 0.000 or $F<0.05$. The coefficient of determination $R$ Square is used to show how large the percentage of work expectations and family environment variables together influencing the variable of interest in continuing master's studies. The results of multiple regression analysis show that the coefficient of determination R2 has a value of 0.306 or it can be said that $30.60 \%$ of the attitude of interest in continuing to study Masters is influenced by the variables of work expectations and family environment. While the remaining $69.40 \%$ is influenced by other variables that have not been included in this research.

Based on these results, it can be said that Djaali (2012) and Slameto (2010) stated that work expectations and work environment have an influence in determining interest in continuing studies at a higher level. By growing interest in continuing their master's studies, students will improve literacy according to their scientific fields, especially students majoring in economics education. That the higher the education level of students majoring in economics education will also increase their economic literacy (Efendi, Indartono, \& Sukidjo, 2019). In continuing their interest in education in the era of the Covid-19 virus pandemic, every student can study online to improve economic literacy for economic education students because the world of Indonesian education is currently still implementing face-to-face learning (Milla et al, 2021). Online learning will add variations to how to learn in the context of multicultural learning in Indonesia (Pratiwi et al, 2020). So it can be said that in the online learning process in the era of the Covid-19 pandemic, policy leaders who have good leadership styles must be needed in making the right policies, especially in the world of education. (Efendi, 2020)

\section{Conclusion}

Based on the results and discussion in the research, we can conclude that: 1). Work expectations have a positive and significant influence on interest in continuing master's studies, 2). Family 
environment has a positive and significant influence on interest in continuing master's studies, 3). Work expectations and family environment together affect the interest in continuing their master's studies by $30.60 \%$ and by $69.40 \%$ are influenced by variables outside the research. Together with the limitations in this research, it can be used as reference material for further research in the future.

\section{References}

Blanchard, K. H., \& Hersey, P. (1996). Great ideas revisited. Training \& Development, 50(1), 42-48.

Djaali, H. (2012). Psikologi Pendidikan. Jakarta: PT Bumi Aksara.

Efendi, R., Indartono, S., \& Sukidjo, S. (2019). The Relationship of Indonesia's Poverty Rate Based on Economic Growth, Health, and Education. International Journal of Multicultural and Multireligious Understanding, 6(2), 323-330.

Efendi, R., Indartono, S., \& Sukidjo, S. (2019). The Mediation of Economic Literacy on the Effect of Self Control on Impulsive Buying Behaviour Moderated by Peers. International Journal of Economics and Financial Issues, 9(3), 98.

Efendi, R. (2020). Pengaruh Gaya Kepemimpinan Terhadap Kinerja Karyawan. Jurnal Economic $E d u, 1(1)$.

Efendi, R., Rifa'i, M. N., Bahrun, K., Milla, H., \& Suharmi, S. (2020). The mediation of work motivation on the effects of work discipline and compensation on performance batik msmes employees in yogyakarta city, indonesia. International Journal of Multicultural and Multireligious Understanding, 7(1), 689-703.

Ikhsan, F. (2008). Dasar-Dasar Kependidikan Komponen MKDK. Jakarta: PT Rineka Cipta.

Milla, H., Yusuf, E., Suharmi, S., Zufiyardi, Z., Efendi, R., \& Annisa, A. (2021). Analysis of the Implementation of Online Learning During Covid-19. International Journal of Multicultural and Multireligious Understanding, 8(4), 538-544.

Porter, L. W., \& Lawler, E. E. (1968). What job attitudes tell about motivation (pp. 118-126). Harvard Business Review Reprint Service.

Pangestu, E. S., Muhyadi, M., \& Efendi, R. (2019). The Intelligence Relations; Emotional, Intellectual, and Spiritual to Students' Ethical Attitudes. International Journal of Multicultural and Multireligious Understanding, 6(6), 563-571.

Pratiwi, D., Widayati, A., \& Efendi, R. (2020). The Implementation of Multicultural Education in Economic Learning. International Journal of Multicultural and Multireligious Understanding, 7(11), 112-118.

Salima, R. L. (2019). Pengaruh Motivasi Belajar dan Lingkungan Keluarga terhadap Minat Melanjutkan Studi Pascasarjana (S-2) Mahasiswa Pendidikan Ekonomi FKIP UNS Angkatan 2015-2016.

Sartain, H. W. (1989). Nonachieving Students at Risk: School, Family, and Community Intervention. National Education Association Professional Library, PO Box 509, West Haven, CT 06516 (Stock No. 3074-5)

Slameto. (2010). Belajar dan Faktor-faktor Yang Mempengaruhinya. Jakarta: PT Rineka Cipta. 
Sugiyono. (2015). Metode Penelitian Pendidikan (pendekatan kuantitatif, Kualitatif, dan R\&D. Bandung: Alfabeta.

Sumakta, I. A. (2015). Pengaruh Prestasi Belajar, Pendapatan Orang Tua, Ekspektasi Kerja Terhadap Minat Melanjutkan Studi Ke S2 Pada Mahasiswa Pendidikan Ekonomi FE UNY. Skripsi. Universitas Negeri Yogyakarta.

Syarbini, A. (2014). Model Pendidikan Karakter Dalam Keluarga. Elex Media Komputindo.

Syah, M. (2012). Psikologi Belajar. Jakarta: PT. Raja Grafindo Persada..

Taufik, S., \& Kurniawati, T. (2020). Pengaruh Kondisi Sosial Ekonomi Keluarga, Prestasi Belajar, dan Kesempatan Kerja Terhadap Minat Melanjutkan Pendidikan ke Program Magister Fakultas Ekonomi UNP. Jurnal Ecogen, 3(1), 49-60.

Ulfa, L. D. R. (2018). Pengaruh Prestasi Belajar, Kondisi Lingkungan Keluarga Dan Ekspektasi Kerja Terhadap Minat Melanjutkan Studi S2 Pada Mahasiswa Pendidikan Ekonomi Fe Uny Angkatan 2014.

Umar, T. \& la sulo. 2005. Pengantar Pendidikan. Jakarta: PT Rineka Cipta.

Wiyono, T. (2017). Pengaruh Latar Belakang Pendidikan Orang Tua, Kondisi Ekonomi Orang Tua Dan Lingkungan Sosial Terhadap Minat Melanjutkan Studi Ke Jenjang S2 Mahasiswa Pendidikan Ekonomi Fakultas Ekonomi UNY. Skripsi: Universitas Negeri Yogyakarta.

Witherington, H. C. (1999). Educational Psychology diterj. oleh M. Buchari: Psikologi Pendidikan.

Yusuf, E., \& Efendi, R. (2019). Student Entrepreneurial Interests that are influenced by Income Expectations, Entrepreneurship Education, and Self Efficacy. International Journal of Multicultural and Multireligious Understanding, 6(6), 572-580.

\section{Copyrights}

Copyright for this article is retained by the author(s), with first publication rights granted to the journal.

This is an open-access article distributed under the terms and conditions of the Creative Commons Attribution license (http://creativecommons.org/licenses/by/4.0/). 